\title{
Perancangan Sistem Informasi Pengingat Kontrol Aset Barang Berbasis Android Pada PT. ISUZU
}

\author{
Christian Boy Aritonang ${ }^{1}$, Andrew Fernando Pakpahan*2, Yulianus Palopak ${ }^{3}$ \\ ${ }^{1}$ PT. Graha Informatika Nusantara, Jakarta, Indonesia \\ ${ }^{2}$ Fakultas Teknologi Informasi, Universitas Advent Indonesia, Bandung, Indonesia \\ ${ }^{3}$ Dept. Information Engineering, National Taiwan University of Science and Technology, Taiwan \\ e-mail: 1christianarios185@gmail.com,*2andrew@unai.edu, ${ }^{3}$ yulianus.palopak@gmail.com
}

\begin{abstract}
Abstrak
Seiring berkembangnya zaman, teknologi sangat dibutuhkan oleh manusia dalam melakukan pekerjaan. Seperti pada perusahaan PT. ISUZU, di mana perusahaan ini memerlukan suatu alat yang dapat membantu pekerja dalam mengingat untuk pengontrolan barang. Salah satu alat yang dapat membantu pekerja dalam mengingat untuk pengontrolan barang adalah perangkat mobile, perangkat ini dapat memberikan reminder terhadap pekerja untuk pengontrolan barang. Dalam hal ini sistem ini diharapkan dapat membantu para pekerja dalam pengontrolan barang dengan baik. Metode yang dipakai dalam penelitian ini adalah metode SDLC (System Development Life Cycle) yaitu dimulai dari Analisa kebutuhan, design system, coding dan testing. Tujuan dari penelitian ini adalah untuk membantu para pekerja dalam mengontrol barang dengan baik melalui sistem aplikasi yang akan dibangun. Hasilnya, perancangan aplikasi reminder kontrol barang dirancang dengan berbasis Android yang dapat digunakan pada mobile phone, dan dapat memberikan reminder atau pengingat kepada pekerja dalam pengontrolan barang, dengan adanya fitur laporan kerja, admin dapat melihat hasil kerja dari para pekerja ICL, perancangan sistem dibangun dengan dua sistem yang berbeda yaitu web dan Android yang dapat menghubungkan admin dengan pekerja.
\end{abstract}

Kata Kunci: sistem informasi, aplikasi pengingat, aplikasi Android, aplikasi web

\section{Design of Reminder Application for Controlling Goods Asset Based on Android in PT. ISUZU}

\begin{abstract}
In this modern days, humans really need technology in their daily life, like PT.ISUZU. where this business need one thing that can help the workers in remembering to control the items. One thing that can help the workers are device that can give reminder to them about things that need to be controlled. In this case, the system is counted to help the workers in controlling the items well. The method that are used in this research is SDLC method (System Development Life Cycle) which was started from needs analysis, design system, coding and testing. The purpose of this research is to help the workers in controlling the items well through application system that will be built. As a result, the Android-based information system reminder control can help the workers in remembering to control items through notifications that were given by the device to the workers.
\end{abstract}

Keywords: information system, reminder application, Android application, web application 


\section{Pendahuluan}

Di era modern ini, perkembangan ilmu pengetahuan dan teknologi sangatlah dibutuhkan, khususnya dalam dunia teknologi informasi yang dirasakan sangat mempengaruhi setiap aspek kehidupan manusia. Seperti di dalam perusahaan, bisnis, pemerintahan, pendidikan, maupun industri peranan Teknologi Informasi (TI) menjadi salah satu alat yang sangat dibutuhkan untuk membantu manusia dalam melakukan tugas dan pekerjaan menjadi lebih cepat, tepat, dan akurat. Dengan kemajuan teknologi tersebut, sistem informasi menjadi kebutuhan yang utama pada setiap lembaga ataupun instansi agar dapat disajikan.

PT.ISUZU adalah perusahaan Jepang yang berada di KIIC (Karawang International Industrial City), perusahaan ini bergerak di bidang manufaktur. Dan memiliki begitu banyak barang yang akan dikontrol. Sebelumnya perusahaan tersebut belum memiliki sistem untuk pengingat kontrol barang yang dapat memberitahukan jadwal pengontrolan atau pengecekan barang, sehingga membuat pekerja menjadi susah untuk melakukan kontrol atau pemeriksaan. Oleh sebab itu barang-barang di dalam perusahaan tidak terkontrol dengan baik.

Pengingat kontrol barang (reminder contro/ barang) adalah sebuah sistem yang dapat memberikan alarm untuk pengontrolan barang berbasis online, sistem ini digunakan untuk memberitahukan barangbarang yang akan dikontrol sesuai dengan tanggal yang telah ditentukan, sehingga dengan demikian dengan adanya sistem tersebut barang-barang dapat terkontrol dengan baik. Dalam kehidupan sehari-hari manusia terkadang susah untuk mengingat bahkan lupa dengan tugas-tugas yang akan dikerjakan. Oleh sebab itu dibutuhkan suatu sistem pengingat untuk membantu manusia dalam mengerjakan tugas-tugas tersebut.

Dengan demikian, untuk menghindari masalah tersebut maka diperlukan adanya sebuah teknologi informasi yang dapat memberitahukan pengontrolan barang kepada para pekerja sehingga barang yang ada pada perusahaan tersebut dapat terkontrol dengan baik. Teknologi tersebut adalah teknologi pengingat kontrol barang, teknologi ini akan digunakan oleh pekerja khususnya orang-orang yang bekerja dibidang pergudangan atau pekerja ICL (Inventory Control Logistics) dan teknologi tersebut akan dibangun dan dibuat berbasis Android yang bisa digunakan di mobile phone.

\section{Tinjauan Pustaka}

\section{Sistem Informasi}

Menurut Asmara [1] bahwa sistem adalah "kumpulan dari elemen-elemen ataupun sub sistem yang saling berikatan dan berinteraksi satu sama lainnya dan tidak dapat dipisahkan serta menuju suatu kesatuan untuk mencapai suatu tujuan". Menurut Aqil [2] bahwa informasi adalah merupakan data yang diolah yang menjadi data yang bermanfaat kemudian diproses menjadi sebuah informasi yang relevan dan bermanfaat kepada orang lain. Menurut Faizal [3] bahwa sistem informasi adalah suatu data yang dihimpun, kemudian di proses menjadi sebuah informasi yang saling menguatkan atau saling mendukung satu dengan dan menjadi sebuah informasi yang berguna dan bermanfaat kepada orang lain.

Berdasarkan pengertian dari beberapa ahli di atas mengenai sistem informasi, maka dapat disimpulkan bahwa sistem informasi merupakan kumpulan dari beberapa komponen yang di proses menjadi sebuah informasi kemudian dikumpulkan menjadi satu dengan tujuan untuk menyediakan sebuah informasi kepada orang yang membutuhkan.

\section{Basis Data}

Menurut Iskandar, dkk [4], basis data adalah merupakan tempat penyimpanan dua atau lebih data yang disimpan dengan di dalamnya ada elemen-elemen data penghubung, yang bisa di akses lebih dari satu cara. Basis data dapat dinyatakan dengan teknik yang formal dan manajemen basis data dari definisi tersebut maka dapat dikatakan bahwa basis data adalah kumpulan dari beberapa data yang saling berhubungan satu dengan yang lain. 


\section{Penelitian Terdahulu}

Putri, dkk [5] melakukan penelitian untuk merancang sebuah sistem yang dapat membantu dalam mengingat tanggal kadaluwarsa produk makanan. Aplikasi ini dapat menjadi salah satu cara dalam membantu pekerja supermarket mengingat tanggal kadaluwarsa dengan menampilkan alarm dan daftar barang yang akan kadaluwarsa. Athoillah dan Irawan [6] melakukan penelitian untuk merancang sebuah sistem dalam membantu pekerjaan pencatatan data barang masuk maupun barang keluar. Sistem ini juga dirancang seluruh transaksi penerimaan dan pengiriman barang dan memantau seluruh proses pengeluaran dan penerimaan barang serta persediaan barang di perusahaan di mana pun saja selama berada dalam jangkauan internet

\section{Analisa dan Perancangan Sistem}

\section{Sejarah PT. Isuzu}

PT. Asian Isuzu Casting Center (AICC) berdiri pada bulan April tahun 1997 sebagai perusahaan Jepang yang bergerak dalam bidang manufaktur pengecoran logam. Pada awal berdiri perusahaan ini masih bernama PT. Astra Isuzu Casting Company baru setelah adanya perubahan struktur kepemilikan saham, pada tahun 2004 berubah nama menjadi PT. Asian Isuzu Casting Center. PT. Asian Isuzu Casting Center berlokasi di Kawasan Industri KIIC Karawang dengan jumlah karyawan pada tahun 2014 sekitar 569 orang, terdiri dari karyawan kontrak dan permanen. Sedangkan luas tanah sekitar 78,854 m2 dan luas bangunan 32,295 m2. Kepemilikan modal seluruhnya (100\%) sebagai perusahaan PMA Jepang yang dipegang oleh 3 (tiga) pemegang saham yaitu, I Metal Technology Co., Ltd., Isuzu Motor Asia Limited, Isuzu Motor Limited.

Pada tahun 2007 PT. Asian Isuzu Casting Center mendapatkan sertifikat ISO 9001:2000 yang menunjukkan komitmen perusahaan terhadap Sistem Manajemen Mutu (Quality Management System). Berikutnya ditahun 2010 PT. Asian Isuzu Casting Center mendapatkan sertifikat ISO 14001:2004 untuk bidang Sistem Manajemen Lingkungan.

\section{Analisa Kebutuhan Sistem}

ICL (Inventory Control Logistics) adalah sebuah departemen di PT.ISUZU yang bertugas atau bekerja dalam pergudangan barang inventori di perusahaan PT.ISUZU. departemen ini mengatur semua in/out barang yang ada pada perusahaan dan sekaligus bekerja dalam pengecekan barang. Adapun pekerja ICL adalah berjumlah dua puluh lima orang dan sebagian di antaranya bekerja dalam pengecekan barang yang berjumlah 5 orang. Adapun barang yang akan di cek/dikontrol adalah seperti Mesin CMM Mitutoyo, Mesin SAM Analis Material, Jembatan Timbang, Nikon Microscope, Plotter 3D printer, AC, Apar.

Dalam proses pengontrolan barang tersebut mempunyai jenis karakteristik waktu antara lain:

1. CMM Mitutoyo (3 bulan)

2. SAM Analis material ( 2 bulan)

3. Jembatan Timbang (3 bulan)

4. Nikon Microscope (2 bulan)

5. Plotter 3D printer (2 bulan)

6. AC (2 bulan)

7. Apar (2 bulan)

Dalam merancang sistem ini, penulis menganalisis beberapa fungsi-fungsi yang dibutuhkan dalam web sebagai berikut:

1. Admin bisa login untuk masuk ke dalam sistem.

2. Admin dapat memasukkan atau input barang ke dalam sistem.

3. Admin dapat melihat data semua barang yang telah dimasukkan ke dalam sistem.

4. Admin dapat menambahkan pekerja untuk membuat password dan username, supaya pekerja dapat menggunakannya ketika masuk ke dalam sistem Android. 
5. Admin dapat melihat laporan pekerja dan dapat melakukan pengiriman pesan ke pekerja ketika ada barang yang tiba-tiba rusak.

6. Pekerja dapat login untuk masuk ke dalam sistem.

7. Pekerja dapat untuk melihat notifikasi pemberitahuan barang.

8. Pekerja dapat melaporkan pekerjaan.

\section{Use Case Diagram}

Sistem ini terdiri dari 2 (satu) user yaitu admin selaku pengguna web dan pekerja selaku pengguna Android, yang memiliki hak akses pada sistem. Di bawah ini adalah gambar dari use case diagram web dan Android tersebut:

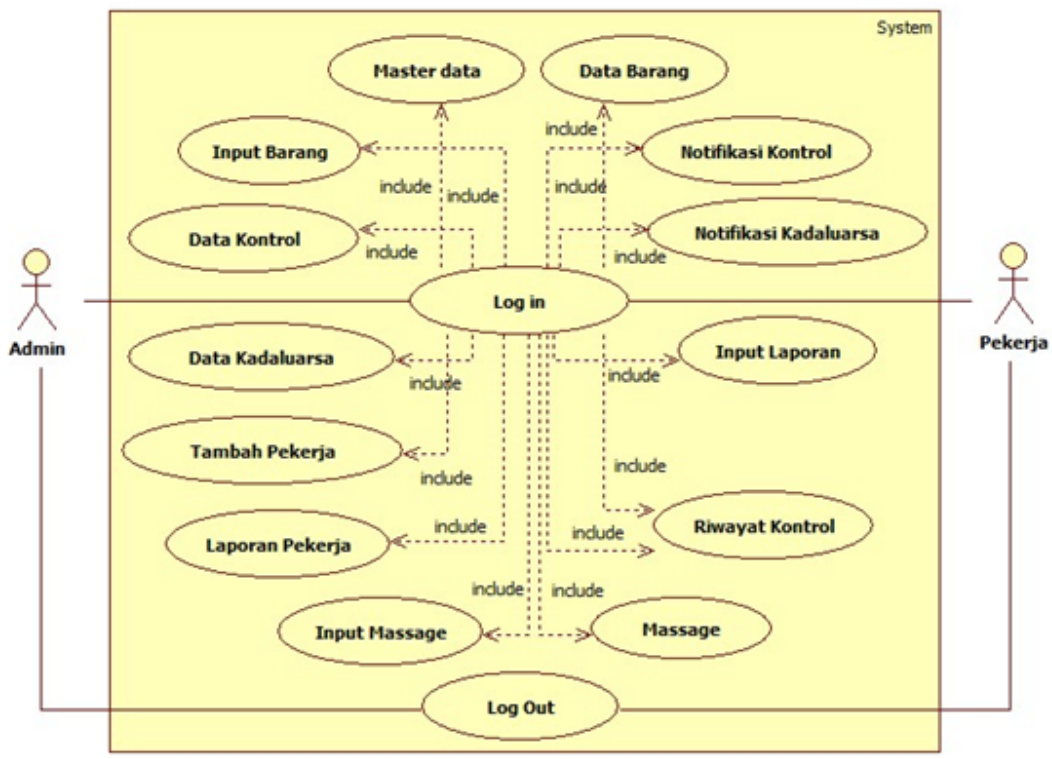

Gambar 1 Use Case Diagram Aplikasi

Adapun penjelasan dari use case diagram di atas adalah sebagai berikut:

a. Admin dapat login untuk masuk ke dalam sistem dan logout untuk keluar dari dalam sistem.

b. Admin, dapat melihat master data barang atau data semua barang yang masuk.

c. Admin, dapat melakukan input, edit, hapus barang pada sistem dan menampilkan barang.

d. Admin, dapat melihat data kontrol, riwayat kontrol data kadaluwarsa.

e. Admin, dapat menambahkan pekerja

f. Admin, dapat melihat laporan kerja dari pekerjanya.

g. Admin, dapat melakukan pesan ke pekerja

h. Pekerja, dapat login untuk masuk ke dalam sistem dan logout untuk keluar dari dalam sistem.

i. Pekerja, dapat melihat notifikasi kontrol barang dan notifikasi kadaluwarsa barang.

j. Pekerja, dapat memasukkan laporan pekerjaan dan mengirimkannya ke admin.

\section{Class Diagram}

Class Diagram dari rancangan sistem kontrol barang berbasis Android ini memiliki 8 entitas yang disertai dengan atribut-atributnya. Class diagram dapat dilihat di Gambar 2 di bawah. 


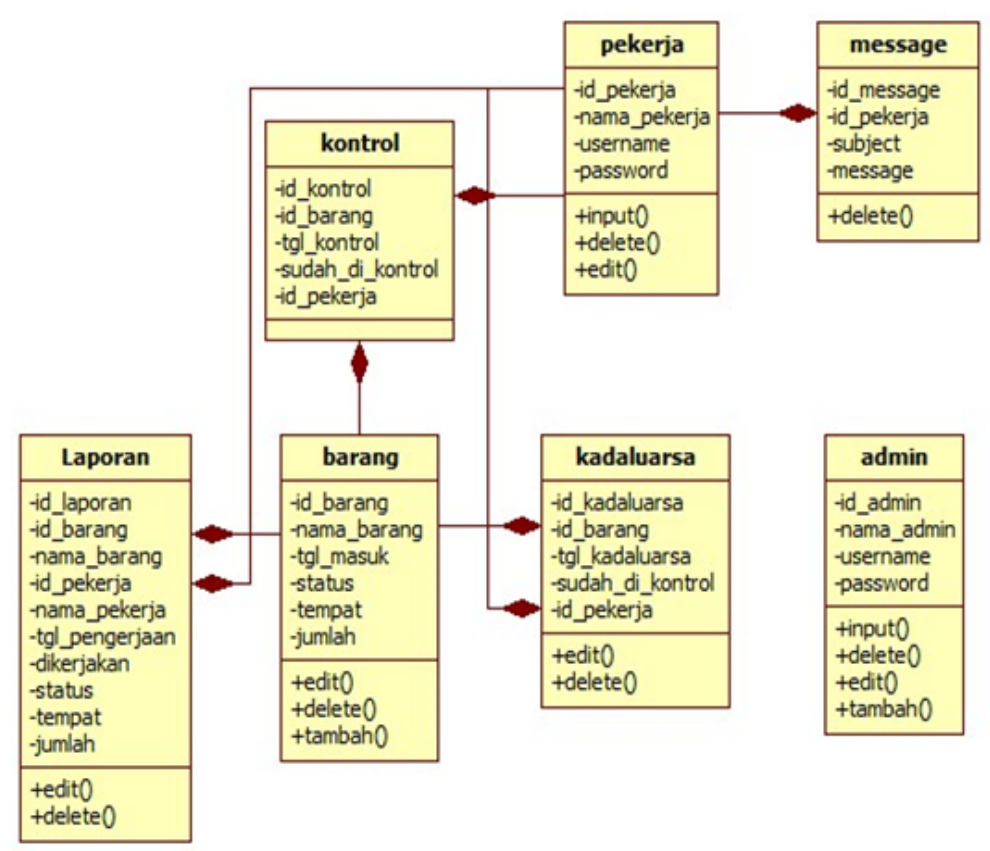

Gambar 2 Class Diagram dari Aplikasi yang dirancang

\section{Perancangan Antar Muka Aplikasi Web}

Perancangan antarmuka menjelaskan rancangan tampilan pada setiap halaman yang akan digunakan pada aplikasi ini. Namun karena keterbatasan tempat, maka hanya beberapa halaman saja yang akan ditampilkan pada tulisan ini. Pada Gambar 3 dapat merupakan tampilan home atau tampilan utama yang memiliki beberapa menu yaitu master data, input barang, data kontrol, data kadaluwarsa, barang keluar, dan laporan kerja. Perancangan tampilan dapat dilihat sebagai berikut.

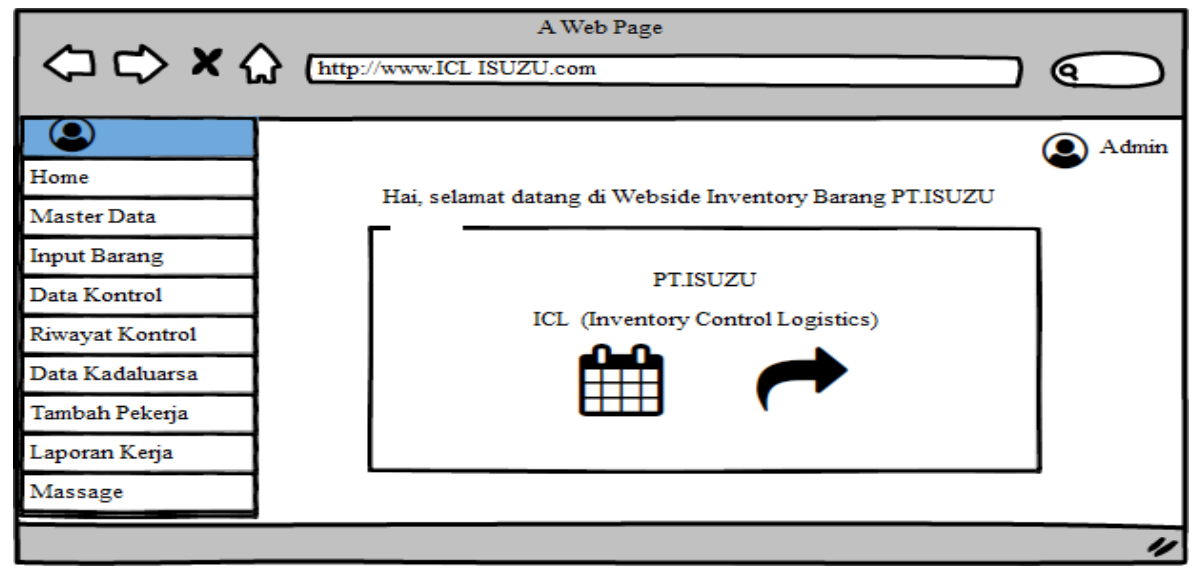

Gambar 3 Desain Tampilan Halaman Utama Aplikasi Web

Gambar 4 menampilkan rancangan tampilan master data barang yang menampilkan semua data barang yang telah dimasukkan. Pada tampilan master data terdapat fitur lain yaitu hapus barang, edit barang, tambah barang keluar, pencarian data dan input barang. 


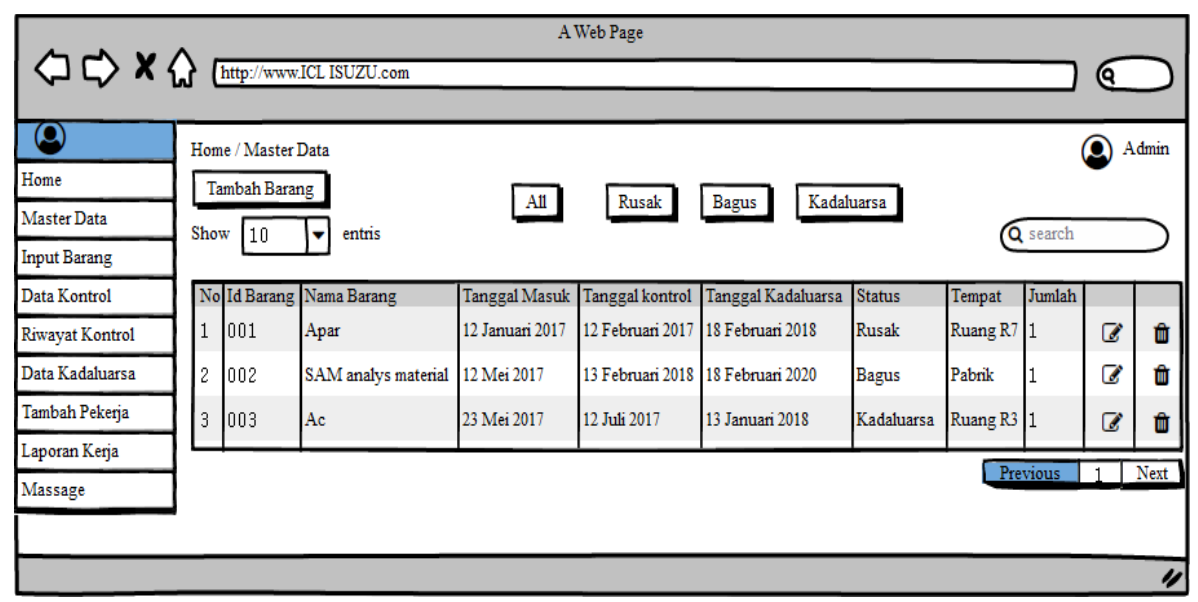

Gambar 4 Desain Tampilan Data Barang

Gambar 5 menampilkan rancangan tampilan input barang. Pada halaman ini, admin dapat memasukkan data-data barang. Data tersebut adalah id_barang, nama barang, tanggal masuk, tanggal kontrol, tanggal kadaluwarsa, status, tanggal keluar tempat dan jumlah, kemudian admin menekan Simpan untuk menyimpan data tersebut. Gambar 6 menampilkan data kontrol barang di mana ditampilkan semua data barang yang perlu dikontrol dan status kontrolnya.

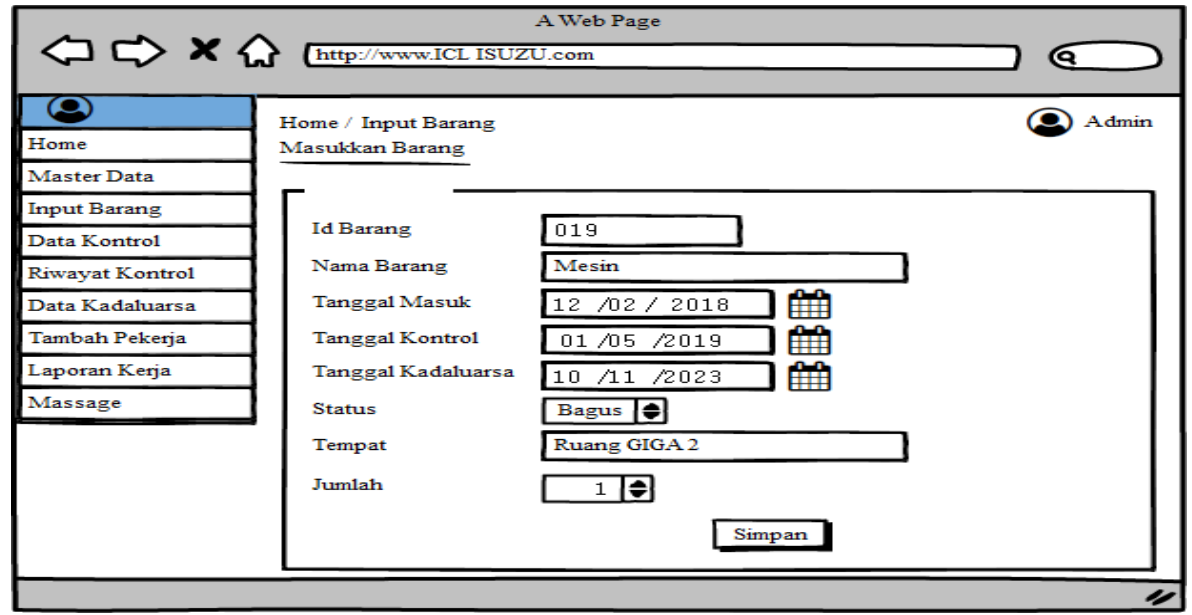

Gambar 5 Desain Tampilan Input Barang

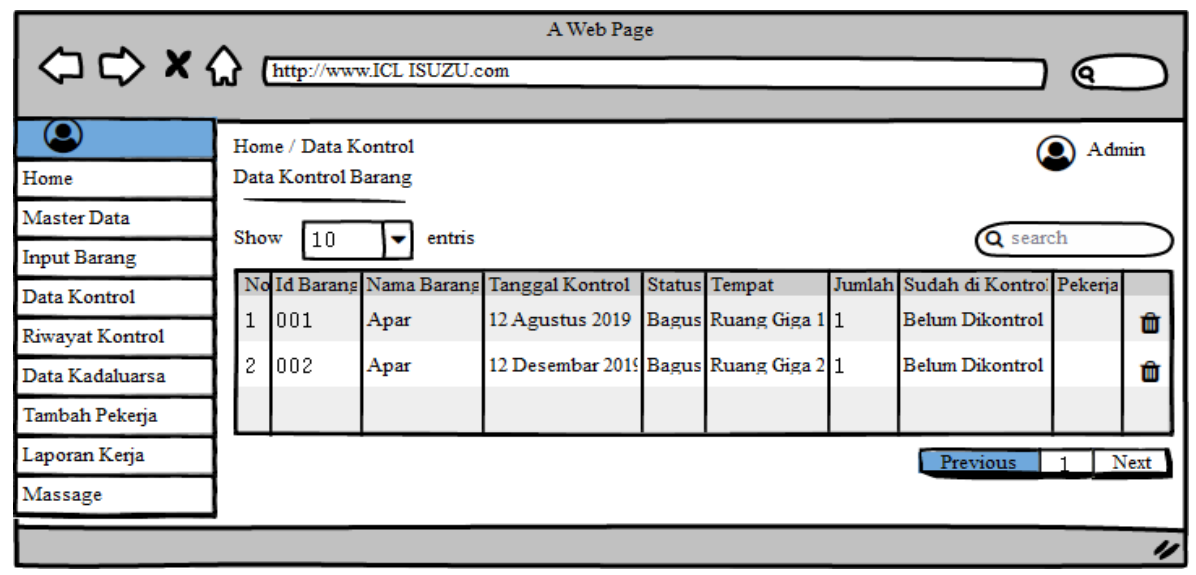

Gambar 6 Desain Tampilan Data Kontrol barang 


\section{Perancangan Antar Muka Aplikasi Android}

Gambar 7 (a) menampilkan rancangan tampilan antar muka aplikasi Android pada saat aplikasi dibuka untuk pertama kali. Pekerja yang akan masuk ke dalam sistem harus melakukan login terlebih dahulu untuk dapat masuk ke dalam sistem. pekerja akan memasukkan username dan password pada form login lalu menekan tombol Sign In. Gambar 7 (b) merupakan tampilan home atau tampilan utama yang ditampilkan setelah pekerja berhasil masuk ke aplikasi dan memiliki beberapa menu yaitu data barang, notifikasi kontrol, notifikasi kadaluwarsa, laporan kerja.

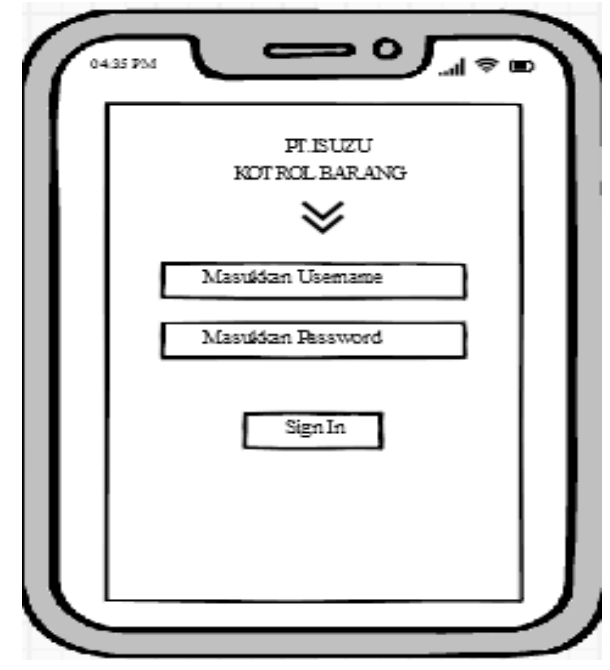

(a)

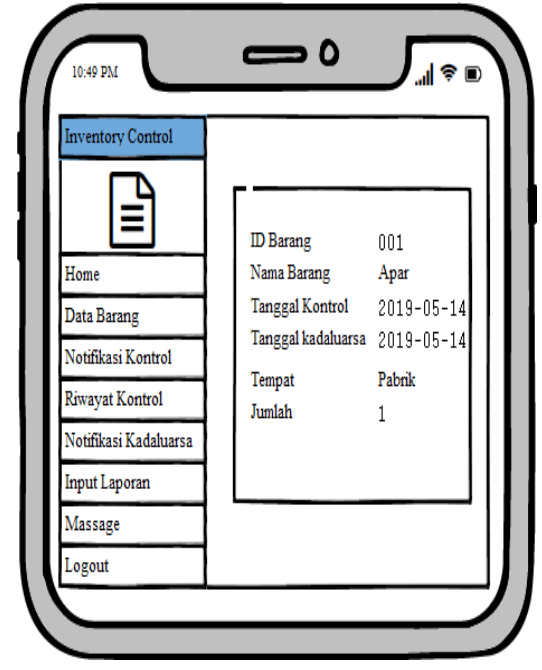

(b)

Gambar 7 Desain Tampilan Aplikasi Android (a) Halaman Login (b) Halaman Data Barang

Gambar 8 (a) menunjukkan tampilan untuk memasukkan laporan pekerjaan dari pekerja. Kemudian laporan tersebut dikirim ke admin, sebagai bukti pengerjaan barang yang telah dikerjakan. Berikut adalah tampilan antarmuka laporan kerja. Gambar 8 (b) menunjukkan tampilan untuk menampilkan alert notifikasi barang di halaman utama aplikasi Android di mobile phone.

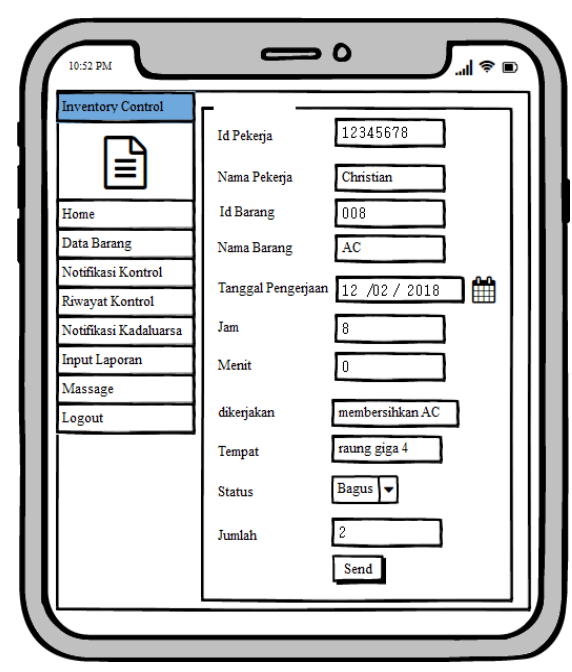

(a)

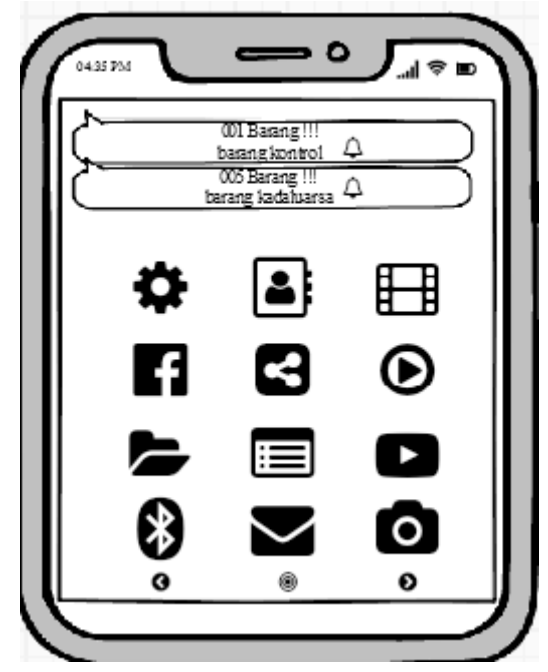

(b)

Gambar 8 Desain Tampilan Aplikasi Android (a) Input laporan kerja (b) Notifikasi kontrol barang di Android 


\section{Hasil Perancangan Aplikasi Web dan Android dan Uji Coba}

Rancangan yang telah dijabarkan pada bagian sebelumnya telah dituangkan dalam bentuk aplikasi web yang dibuat dengan menggunakan bahasa pemrograman PHP dan menggunakan server database MySQL di atas komputer dengan spesifikasi: Processor Intel Core i3, RAM 4GB, Harddisk 500GB.

\section{Aplikasi Web}

Gambar 9 menampilkan hasil perancangan aplikasi yang menampilkan tampilan kontrol barang pada aplikasi web yang dikembangkan. Pada menu di sebelah kiri halaman terdapat fungsi-fungsi yang dapat diakses dalam aplikasi web ini.

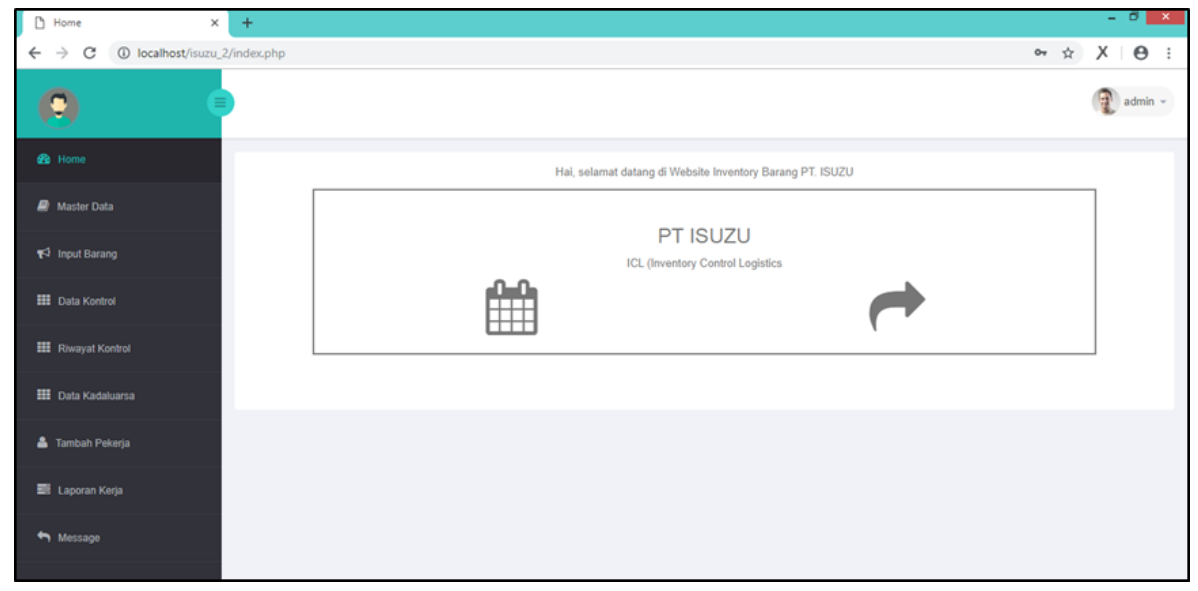

Gambar 9 Tampilan halaman utama pada Aplikasi Web

Gambar 10 menampilkan hasil tampilan kontrol admin akan menambahkan barang ke dalam sistem, barang yang telah di-input akan tersimpan ke dalam master data.

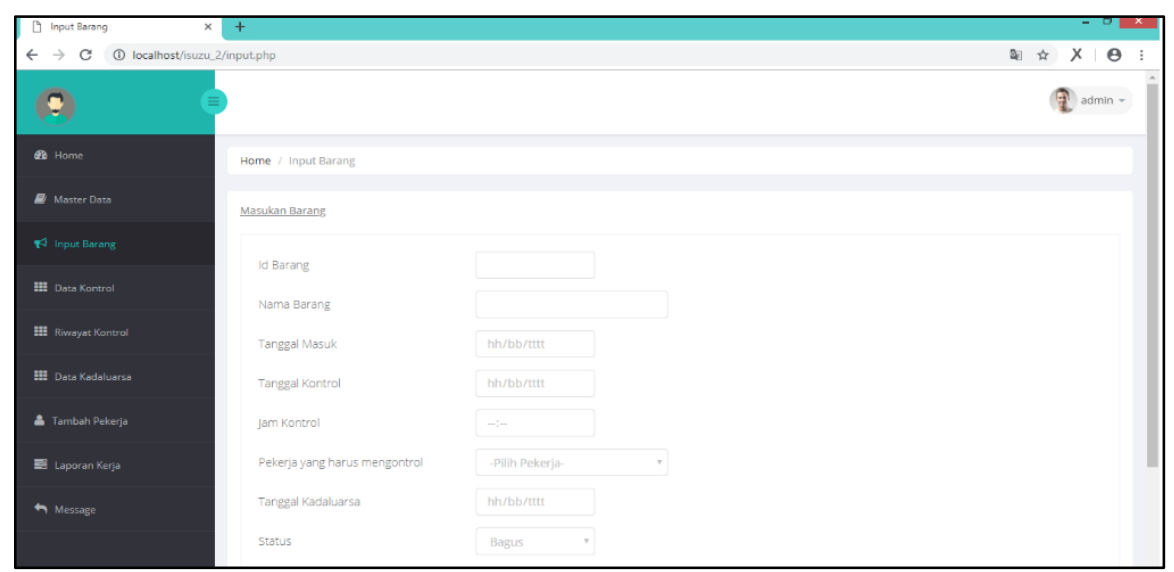

Gambar 10 Tampilan Input Barang pada Aplikasi Web

Gambar 10 menampilkan halaman master data adalah halaman tempat penyimpanan barang yang telah di input oleh admin pada halaman input barang dan tersimpan di master data. Pada halaman ini terdapat beberapa fitur seperti untuk tambah barang, edit barang dan hapus barang. Gambar 10 menampilkan tampilan data-data barang yang belum dikontrol, data tersebut akan ditampilkan pada halaman ini. 


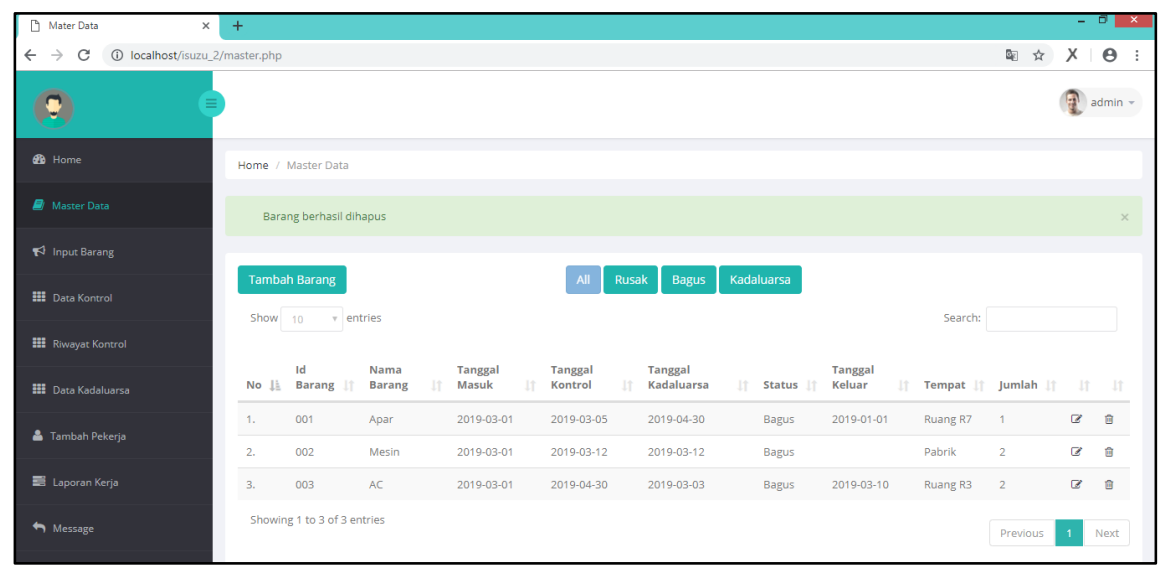

Gambar 10 Tampilan Master Data Pada Aplikasi Web

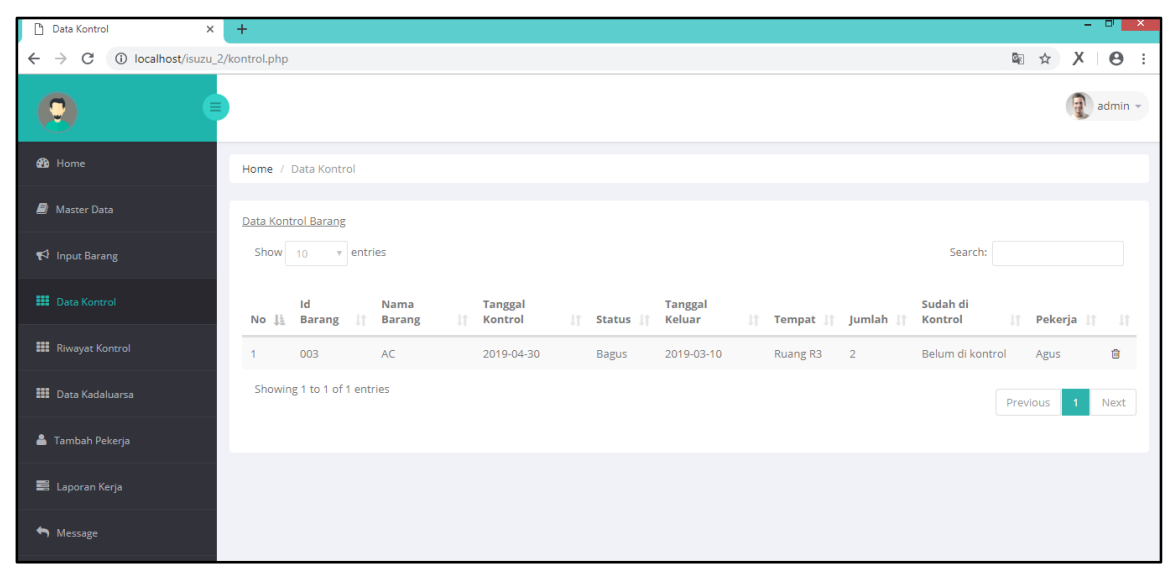

Gambar 11 Tampilan Data Kontrol barang

\section{Aplikasi Android}

Untuk dapat mengakses halaman utama aplikasi Android, pekerja harus terlebih dahulu memasukkan username dan password yang benar di halaman Login, seperti yang dapat dilihat di Gambar 12 (a). Jika username dan password dimasukkan tidak sesuai dengan yang ada di database, maka akan muncul pemberitahuan "Username dan Password yang anda masukkan salah". Sedangkan jika benar, maka akan muncul halaman Home seperti di Gambar 12 (b).

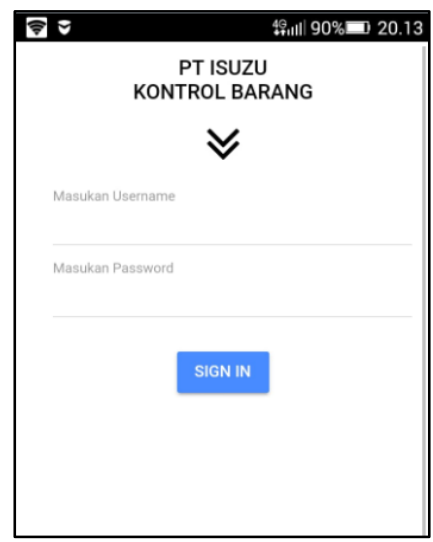

(a)

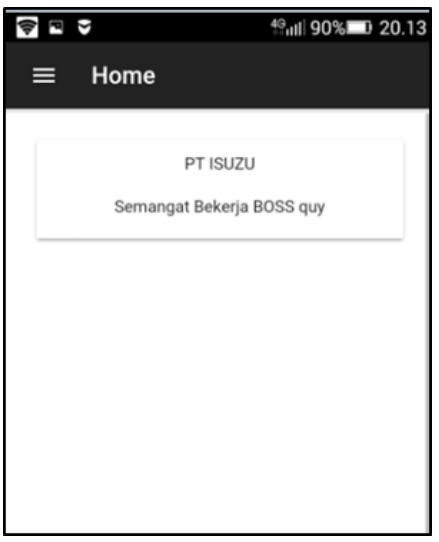

(b)

Gambar 12 Tampilan Aplikasi Android (a) Tampilan login (b) Tampilan halaman Home 
Gambar 13 (a) menampilkan halaman input laporan untuk membuat laporan kerja dari pekerja yang berisi id pekerja, nama pekerja, id barang, nama barang, tanggal pengerjaan, yang dikerjakan, tempat, status, jumlah dan kemudian di kirim ke web admin, untuk memberitahukan apa saja yang dikerjakan oleh pekerja pada barang tersebut. Gambar 13 (b) menampilkan tampilan Message untuk menampilkan pesan yang dikirimkan oleh admin kepada para pekerja.

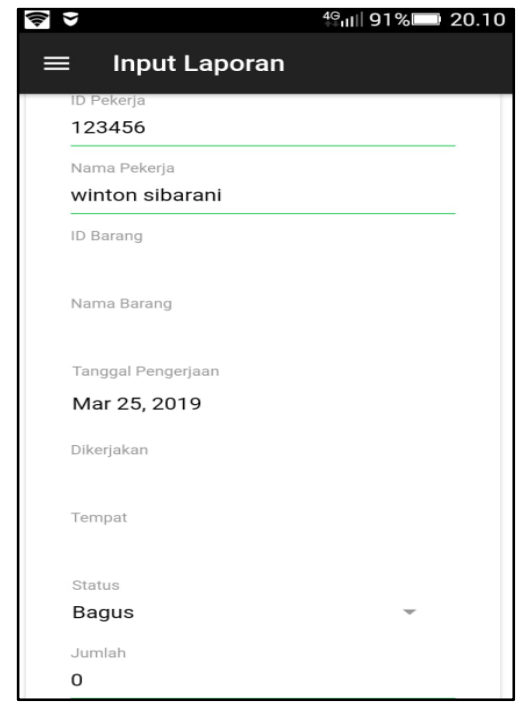

(a)

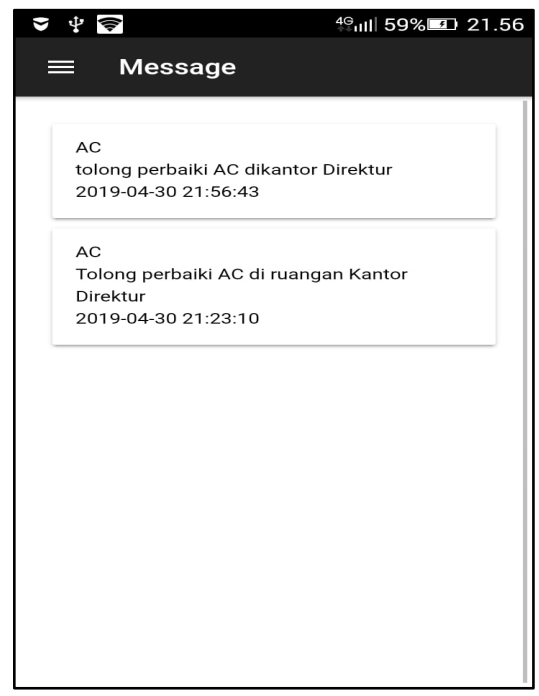

(b)

Gambar 13 Tampilan Data Kontrol barang

Gambar 14 menunjukkan tampilan alert notifikasi adalah tampilan untuk menampilkan notifikasi barang-barang yang sudah jatuh tempo waktu

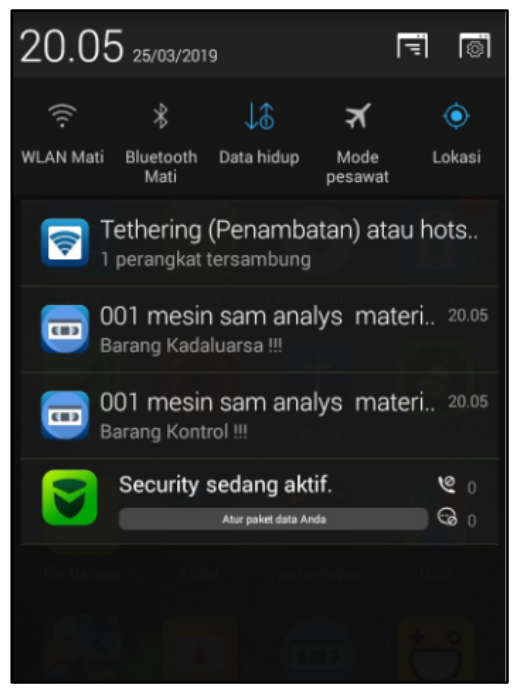

Gambar 14 Tampilan Alert Notifikasi

\section{Uji Coba Aplikasi}

Pada tahapan ini pengujian sistem akan dilakukan dengan metode black box, pengujian sistem ini akan dilakukan secara bertahap mulai dari proses pertama hingga proses terakhir. Tujuannya adalah untuk mengetahui hasil apakah sistem tersebut sudah layak atau berfungsi sesuai dengan yang diharapkan atau tidak. Tabel 1 dan 2 menampilkan hasil pengujian yang dilakukan dan semua pengujian yang dilakukan berhasil dengan baik. 
Tabel 1 Hasil Pengujian Aplikasi Web

\begin{tabular}{|c|c|c|c|c|}
\hline No. & Form yang diuji & Skenario Uji & Hasil Pengujian & Jenis Pengujian \\
\hline \multirow[b]{2}{*}{1.} & \multirow{2}{*}{ Login } & $\begin{array}{l}\text { Masukkan data username } \\
\text { dan password yang benar }\end{array}$ & $\begin{array}{l}\text { Proses login berhasil dan masuk } \\
\text { kehalaman home }\end{array}$ & $\begin{array}{l}\text { [ }] \text { ] Diterima } \\
\text { [ ] Ditolak }\end{array}$ \\
\hline & & $\begin{array}{l}\text { Masukkan data username } \\
\text { dan password yang salah }\end{array}$ & $\begin{array}{l}\text { Proses login gagal atau sistem } \\
\text { menolak }\end{array}$ & $\begin{array}{l}\text { [V] Diterima } \\
\text { [ ] Ditolak }\end{array}$ \\
\hline \multirow[b]{5}{*}{2.} & \multirow[b]{5}{*}{ Master Data } & $\begin{array}{l}\text { Tambah data barang } \\
\text { dengan dengan id barang } \\
\text { berbeda, lalu klik tambah }\end{array}$ & $\begin{array}{l}\text { Sistem sukses tambah data } \\
\text { barang ke dalam database }\end{array}$ & $\begin{array}{l}\text { [V] Diterima } \\
{[\text { ] Ditolak }}\end{array}$ \\
\hline & & $\begin{array}{l}\text { Tambah data barang } \\
\text { dengan dengan id barang } \\
\text { sama, lalu klik tambah }\end{array}$ & $\begin{array}{l}\text { Sistem menolak untuk } \\
\text { menambahkan barang }\end{array}$ & $\begin{array}{l}{[\sqrt{ }] \text { Diterima }} \\
{[\text { ] Ditolak }}\end{array}$ \\
\hline & & Edit data & $\begin{array}{l}\text { Mengubah data barang yang } \\
\text { sudah tersimpan didalam } \\
\text { database }\end{array}$ & $\begin{array}{l}\text { []] Diterima } \\
{[\text { ] Ditolak }}\end{array}$ \\
\hline & & Hapus data barang & $\begin{array}{l}\text { Menghapus data barang yang } \\
\text { sudah tersimpan didalam } \\
\text { database }\end{array}$ & $\begin{array}{l}{[\sqrt{ }] \text { Diterima }} \\
\text { [ ] Ditolak }\end{array}$ \\
\hline & & Cari data barang & $\begin{array}{l}\text { Sistem akan menampilkan data } \\
\text { yang dicari }\end{array}$ & $\begin{array}{l}\text { [ } \sqrt{]} \text { Diterima } \\
\text { [ ] Ditolak }\end{array}$ \\
\hline \multirow{2}{*}{3.} & \multirow{2}{*}{ Input Barang } & $\begin{array}{l}\text { Input data barang, dengan } \\
\text { id barang berbeda }\end{array}$ & $\begin{array}{l}\text { Sistem sukses tambah data } \\
\text { barang ke dalam database }\end{array}$ & $\begin{array}{l}\text { [1] Diterima } \\
\text { [ ] Ditolak }\end{array}$ \\
\hline & & $\begin{array}{l}\text { Input data barang, dengan } \\
\text { id barang yang sama }\end{array}$ & $\begin{array}{l}\text { Sistem menolak untuk } \\
\text { menambahkan barang }\end{array}$ & $\begin{array}{l}\text { [V] Diterima } \\
\text { [ ] Ditolak }\end{array}$ \\
\hline \multirow[t]{2}{*}{4.} & \multirow[t]{2}{*}{ Data Kontrol } & Hapus data kontrol & $\begin{array}{l}\text { Menghapus data kontrol barang } \\
\text { yang telah tersimpan di } \\
\text { database }\end{array}$ & $\begin{array}{l}{[\sqrt{ }] \text { Diterima }} \\
{[] \text { Ditolak }}\end{array}$ \\
\hline & & Cari data kontrol & $\begin{array}{l}\text { Sistem menampilkan data } \\
\text { barang yang dicari }\end{array}$ & $\begin{array}{l}\text { [ } \sqrt{]} \text { Diterima } \\
\text { [ ] Ditolak }\end{array}$ \\
\hline \multirow[t]{2}{*}{5.} & \multirow[t]{2}{*}{ Riwayat Kontrol } & Hapus data kontrol & $\begin{array}{l}\text { Menghapus data riwayat kontrol } \\
\text { barang yang telah tersimpan di } \\
\text { database }\end{array}$ & $\begin{array}{l}{[\sqrt{ }] \text { Diterima }} \\
{[\text { ] Ditolak }}\end{array}$ \\
\hline & & Cari data riwayat & $\begin{array}{l}\text { Sistem menampilkan data } \\
\text { barang yang dicari }\end{array}$ & $\begin{array}{l}{[\sqrt{ }] \text { Diterima }} \\
\text { [ ] Ditolak }\end{array}$ \\
\hline \multirow[t]{2}{*}{6.} & \multirow[t]{2}{*}{ Data Kadaluwarsa } & Hapus data kadaluwarsa & $\begin{array}{l}\text { Menghapus data kadaluwarsa } \\
\text { barang yang telah tersimpan di } \\
\text { database }\end{array}$ & $\begin{array}{l}{[\sqrt{ }] \text { Diterima }} \\
{[\text { ] Ditolak }}\end{array}$ \\
\hline & & Cari data kadaluwarsa & $\begin{array}{l}\text { Sistem menampilkan data } \\
\text { barang yang dicari }\end{array}$ & $\begin{array}{l}{[\sqrt{ }] \text { Diterima }} \\
{[\text { ] Ditolak }}\end{array}$ \\
\hline \multirow{5}{*}{7.} & \multirow{5}{*}{ Pekerja } & $\begin{array}{l}\text { Tambah data pekerja } \\
\text { dengan id pekerja yang } \\
\text { berbeda }\end{array}$ & $\begin{array}{l}\text { Sistem sukses menambahkan } \\
\text { data pekerja }\end{array}$ & $\begin{array}{l}{[\sqrt{ }] \text { Diterima }} \\
{[] \text { Ditolak }}\end{array}$ \\
\hline & & $\begin{array}{l}\text { Tambah data pekerja } \\
\text { dengan id pekerja yang } \\
\text { sama }\end{array}$ & $\begin{array}{l}\text { Sistem menolak menambahkan } \\
\text { data pekerja }\end{array}$ & $\begin{array}{l}{[\sqrt{ }] \text { Diterima }} \\
{[] \text { Ditolak }}\end{array}$ \\
\hline & & Edit data & $\begin{array}{l}\text { Mengubah data pekerja yang } \\
\text { sudah tersimpan di database }\end{array}$ & $\begin{array}{l}\text { [ } \sqrt{ } \text { ] Diterima } \\
\text { [ ] Ditolak }\end{array}$ \\
\hline & & Hapus data & $\begin{array}{l}\text { Sistem menghapus data yang } \\
\text { sudah tersimpan di database }\end{array}$ & $\begin{array}{l}\text { [1] Diterima } \\
\text { [ ] Ditolak }\end{array}$ \\
\hline & & Cari data & $\begin{array}{l}\text { Sistem menampilkan data yang } \\
\text { dicari }\end{array}$ & $\begin{array}{l}{[\sqrt{]} \text { Diterima }} \\
\text { [ ] Ditolak }\end{array}$ \\
\hline \multirow{2}{*}{9.} & \multirow{2}{*}{ Laporan Pekerja } & Hapus data Laporan & $\begin{array}{l}\text { Menghapus data laporan yang } \\
\text { telah tersimpan di database }\end{array}$ & $\begin{array}{l}\text { [V] Diterima } \\
\text { [ ] Ditolak }\end{array}$ \\
\hline & & Cari data & $\begin{array}{l}\text { Sistem menampilkan data yang } \\
\text { dicari }\end{array}$ & $\begin{array}{l}\text { [V] Diterima } \\
\text { [ ] Ditolak }\end{array}$ \\
\hline
\end{tabular}


Tabel 2 Hasil Pengujian Aplikasi Android

\begin{tabular}{|c|c|c|c|c|}
\hline No. & Form yang di Uji & Skenario Uji & Hasil Pengujian & Jenis Pengujian \\
\hline \multirow{2}{*}{1.} & \multirow{2}{*}{ Login } & $\begin{array}{l}\text { Masukkan data } \\
\text { username dan password } \\
\text { yang benar }\end{array}$ & $\begin{array}{l}\text { Proses login berhasil dan masuk } \\
\text { kehalaman home }\end{array}$ & $\begin{array}{l}\text { [V] Diterima } \\
\text { [ ] Ditolak }\end{array}$ \\
\hline & & $\begin{array}{l}\text { Masukkan data } \\
\text { username dan password } \\
\text { yang salah }\end{array}$ & $\begin{array}{l}\text { Proses login gagal atau sistem } \\
\text { menolak }\end{array}$ & $\begin{array}{l}{[\sqrt{ }] \text { Diterima }} \\
{[\text { ] Ditolak }}\end{array}$ \\
\hline 2. & Notifikasi Kontrol & Klik check data barang & $\begin{array}{l}\text { Masuk ke halaman laporan dan } \\
\text { form riwayat kontrol } \\
\text { menampilkan data barang } \\
\text { kontrol }\end{array}$ & $\begin{array}{l}{[\sqrt{ }] \text { Diterima }} \\
{[\text { ] Ditolak }}\end{array}$ \\
\hline 3. & $\begin{array}{l}\text { Notifikasi } \\
\text { Kadaluarsa }\end{array}$ & Klik check data barang & $\begin{array}{l}\text { Tanda check berubah menjadi } \\
\text { checkout dan form data } \\
\text { kadalursa menampilkan data } \\
\text { barang kadaluarsa }\end{array}$ & $\begin{array}{l}{[\sqrt{ }] \text { Diterima }} \\
{[\text { ] Ditolak }}\end{array}$ \\
\hline \multirow{2}{*}{4.} & \multirow{2}{*}{ Laporan Kerja } & $\begin{array}{l}\text { Mengisi seluruh field } \\
\text { yang ada pada form } \\
\text { input laporan }\end{array}$ & $\begin{array}{l}\text { Data terkirim dan menampilkan } \\
\text { data laporan di form data } \\
\text { laporan kerja }\end{array}$ & $\begin{array}{l}{[\sqrt{ }] \text { Diterima }} \\
{[] \text { Ditolak }}\end{array}$ \\
\hline & & $\begin{array}{l}\text { Mengisi sebagian field } \\
\text { yang ada pada form } \\
\text { input laporan }\end{array}$ & Data tidak terkirim & $\begin{array}{l}{[\sqrt{ }] \text { Diterima }} \\
{[\text { ] Ditolak }}\end{array}$ \\
\hline
\end{tabular}

\section{Kesimpulan dan Saran}

Berdasarkan hasil perancangan sistem informasi pengingat kontrol barang pada PT.ISUZU, dapat disimpulkan sebagai berikut:

1. Dengan membangun sebuah aplikasi berbasis Android pada mobile phone, yang dapat memberikan reminder atau pengingat kepada pekerja dalam pengontrolan barang.

2. Dengan menambahkan fitur laporan kerja, dengan demikian admin dapat melihat hasil kerja dari para pekerja ICL.

3. Dengan membangun dua sistem yaitu web dan Android yang dapat menghubungkan admin dengan pekerja.

Sedangkan sebagai saran untuk mengembangkan sistem ini ke depannya dapat dikembangkan agar sistem ini dapat menghitung statistik/jumlah tiap barang yang telah dikontrol, kadaluwarsa, barang yang bagus, barang yang rusak dan menghitung jumlah data barang yang telah dikerjakan tiap pekerja. Kemudian diharapkan agar database sistem ini menggunakan database yang terintegrasi dengan sistem yang ada pada perusahaan PT.ISUZU.

\section{Daftar Pustaka}

[1] R. Asmara, "Sistem Informasi Pengolahan Data Penanggulangan Bencana Pada Kantor Badan Penanggulangan Bencana Daerah (BPBD) Kabupaten Padang Pariaman," Jurnal J-Click, vol. 3, no. 2, pp. 80-91, 2016.

[2] I. Aqil, "Sistem Informasi Alumni Program Diploma Pada Bina Sriwijaya Palembang Berbasis Web," Jurnal Iptek, pp. 4-6, 2010.

[3] M. Faizal, "Sistem Informasi Pengolahan Data Pegawai Berbasis Web (Studi Kasus DI PT.Perkebunan Nusantara VIII Tambaksari)," Jurnal Teknologi Informasi dan Komunikasi, vol. 12, no. 1, pp. 1-23, 2017. 
[4] A. Iskandar dan A. H. Rangkuti, "Perancangan Sistem Informasi Penjualan Tunai Pada PT. Klaten Bercahaya," Jurnal Basis Data, vol. 3, no. 2, pp. 124-131, 2008.

[5] G. A. Putri, J. N. Sari dan I. Surya, "Aplikasi Mobile Untuk Pengingat Waktu Kadaluarsa Barang Dalam Kemasan Beserta Peta Distributor," dalam Seminar Nasional Teknologi Informasi Komunikasi dan Industri, Riau, 2002.

[6] M. Athoillah dan M. I. Irawan, "Perancangan Sistem Informasi Mobile Berbasis Android Untuk Korol Persediaan Barang di Gudang," Jurnal Sains dan Seni Pomits, vol. 1, no. 1, pp. 1-6, 2013. 